\title{
AUTISMOS: UMA CONTRIBUIÇÃO PARA SE PENSAR O SUJEITO EM PSICANÁLISE*
}

Nina Virginia de Araújo Leite**

\section{RESUMO}

A partir de algumas observações clínicas a respeito de crianças autistas, o presente artigo busca identificar aspectos relevantes para avançar na abordagem psicanalítica da subjetividade, especialmente no que respeita à importância da consideração do campo da linguagem e da função da fala no processo de estruturação. Ressalta-se a condição fundamental do gesto simbólico inaugural do nascimento do sujeito, enlaçando o real do organismo na rede discursiva que implica não apenas os ideais sociais, mas principalmente a incidência de um desejo que não seja anônimo.

Palavras-chave: autismos; psicanálise; linguagem; subjetividade.

A primeira observação que o tema desperta é a seguinte: temos verificado um desequilíbrio entre a raridade dos casos de autismos na população e o volume da produção teórica que tem sido escrito a respeito, desde a nomeação da síndrome de Autismo Infantil Precoce por Kanner em 1943. O que esse interesse estaria denotando com relação à condição subjetiva posta em cena nesses casos?

Para indicar uma possível resposta a essa questão, gostaria de partir de uma afirmação que suponho produtiva porque, além de ser também a de alguns autores respeitáveis no campo da psicanálise, é derivada de uma experiência clínica: não há um autismo puro, encontramos sempre singularidades clínicas que estão em desacordo com a clareza das elaborações teóricas isoladas por categorias puras. Esta é uma expli-

\footnotetext{
* Artigo recebido em 16/5/2005 e aprovado em 25/7/2005.

** Professora (Instituto de Estudos da Linguagem da Unicamp) e Psicanalista (Escola de Psicanálise de Campinas). E-mail: nleite@iel.unicamp.br
} 
cação primeira para o plural que está marcado no título: autismos. Portanto, vamos começar afirmando uma dificuldade (o que não quer dizer impossibilidade) para isolar uma categoria que se denominaria "criança autista". O objetivo da nossa reflexão será então poder retirar conseqüências deste ponto de partida e ver o quanto é possível avançar, pois se é fato que a diversidade é a regra, isto não impossibilita, como disse, que se busque construir o que responde estruturalmente pela riqueza clínica dos casos. Nesse sentido, concordamos com Colette Soler, quando afirma que os autismos constituem um pólo, e não uma categoria pura.

Um ponto importante que quero destacar, a partir desse comentário, é a diferença de abordagens que resulta da forma diversa de se tratar os fenômenos clínicos. Ou seja, dependendo da relação que se estabelece com o campo dos fenômenos, tomando-os como transparentes em si mesmos ou como opacidade que deve ser lida em um processo de decifração, teremos formas diferenciadas de abordar o tema em questão. Estou aqui pensando nas diferenças de abordagens que encontramos relacionadas aos autismos, dependendo se estamos nos referenciando no campo da psiquiatria, da psicologia ou da psicanálise. Indico apenas brevemente (seguindo os apontamentos do trabalho de Ângela Vorcaro) que, se na psiquiatria as manifestações da criança são tomadas a partir de um ideal de transcrição e categorização, e se na psicologia o olhar clínico busca realizar uma tradução das manifestações da criança para sentidos previamente dados, a clínica psicanalítica, para a qual o que define a condição da criança é a constituição subjetiva, a formação do inconsciente, as manifestações da criança serão marcadas por uma opacidade que resiste a um código e a sentidos prévios. Essa forma de abordar a criança exige que o clínico realize uma operação de deciframento das manifestações da criança na sua relação com o Outro. Portanto, aquilo que se diz e como se diz sobre a criança fazem parte do texto que deverá ser decifrado.

Mas a pluralidade marcada no título também quer indicar que desde a criação de Kanner o modo de apreender a clínica dos autismos enriqueceu-se consideravelmente pelo viés de numerosas correntes teóricas, às vezes contraditórias, mas fecundas. Podemos citar aqui as diversas metáforas que são utilizadas na descrição dos casos: o buraco negro, a fortaleza vazia, a agonia primitiva, a queda infinita no abismo do não-ser, o grau zero de subjetividade, entre outras. 
É amplamente aceito, atualmente, que a situação de objetificação de uma criança, que pode advir de uma hospitalização longa, de uma doença genética ou induzida por um prognóstico ou diagnóstico médicos, não deixa muito espaço para uma subjetivação e pode produzir uma retirada autista. Condutas autistas também podem aparecer igualmente depois de um acidente neurológico grave ou no curso das transformações da puberdade. Mas se a referência à melancolia materna também demarca uma condição na lista de determinações da condição autista é porque podemos pensar que a clínica do autismo pode evocar uma situação de hospitalismo em domicílio, na qual o impossível olhar do Outro real (a mãe) produz uma falha na necessária constituição do sujeito no Outro. Abordar os autismos com base nessa vertente é produtivo porque justamente nos confronta com questões fundamentais da teoria psicanalítica. Por exemplo: o que preside e determina o processo de estruturação de um sujeito, ou o que é condição necessária para que um sujeito se produza (já que estamos trabalhando com a hipótese de que sujeito não é sinônimo de uma condição dada)? Qual a contribuição que um déficit orgânico tem no fracasso da estruturação subjetiva? Como tratar a importância da presença materna e paterna no advento do sujeito e no fracasso de sua constituição? Qual a incidência do discurso social na construção dos casos de fracasso? Se um trabalho psicanalítico convoca o trabalho na transferência, como sustentá-lo em situações em que a patologia caracteriza-se justamente pela recusa do outro? $\mathrm{O}$ autismo é um quadro típico da infância? Há saída do autismo? Há uma fase autística primitiva pela qual todos os sujeitos passariam? Que diferenças podemos indicar entre o autismo e a psicose na infância? Etc...

A possibilidade de avançarmos respostas para essas e outras tantas questões está na dependência de podermos construir uma inteligibilidade quanto aos processos que presidem a articulação do real do organismo com o lugar simbólico que preexiste ao sujeito, articulação esta sustentada pela via do imaginário materno.

A ênfase posta no papel determinante do agente materno impõe uma observação: desde o trabalho pioneiro de Kanner, estabeleceu-se uma discussão quanto ao papel da mãe na produção dos casos de autismo, embora o próprio Kanner tenha afirmado no seu primeiro trabalho que "essas crianças vêm ao mundo com uma incapacidade inata de constituir biologicamente o contato habitual com as pessoas, exatamente como as outras crianças vêm ao mundo com deficiências físicas ou intelectuais". 
Mas como ele tinha descrito as mães como "frias" e "pouco carinhosas", entendeu-se que ele estaria culpabilizando-as, o que provocou manifestações das mães de autistas que afirmavam que amavam seus filhos. Esse episódio é importante porque nos força a distinguir entre a função social de cuidados que as mães podem desempenhar melhor ou pior e pela qual podem ser julgadas e uma função que em psicanálise chamamos de "função materna", que as mães desconhecem exercer, ou seja, realizam com o não-saber que marca o inconsciente. Ou seja, a função materna implica a estrutura psíquica inconsciente da mãe. E quanto a essa, não há como culpabilizar um sujeito; no entanto, a psicanálise não des-responsabiliza o sujeito quanto ao que o afeta e isto define uma posição do analista no trabalho de escuta junto aos pais, promovendo a responsabilização destes no sintoma do filho. Pois o que se passa entre a mãe e seu bebê implica não apenas os cuidados da sobrevivência, mas, sobretudo, e sabemos disto justamente pelo que o fracasso da estruturação subjetiva testemunha, o exercício de uma função que coloca em jogo o campo da linguagem (a mãe fala com o seu bebê e as palavras atingem o seu corpo) e o campo do gozo (para que as palavras possam de fato atingir o corpo da criança é necessário que o bebê esteja investido imaginariamente em um certo lugar simbólico na estrutura psíquica da mãe).

Vemos, então, que longe da constituição psíquica de um sujeito poder ser pensada como determinada pela integridade neurofisiológica do organismo, é na sua dependência com relação ao campo do simbólico e do imaginário materno que essa tarefa poderá ser realizada. O que fica assim indicado, e que tem a maior importância para pensarmos a clínica dos autismos, é que a referência estruturante para o surgimento do sujeito não está no campo da satisfação ou da frustração das necessidades. Não é o cuidado das necessidades per se que colocará o bebê inserido no campo da linguagem. Não estamos trabalhando com uma hipótese inatista que tomaria como natural a entrada do sujeito no campo que lhe é próprio, ou seja, o campo da palavra. Estamos afirmando que é por um gesto simbólico que essa inclusão da criança na linguagem se dará.

Sabemos que uma característica pregnante nas crianças autistas refere-se ao domínio da linguagem e da fala. Desde a descrição de Kanner, esse fato tem sido observado. Ele observou onze casos para descrever a síndrome; destes, oito adquiriram a capacidade de falar, mas ele nota que a linguagem não era utilizada para a comunicação com outras pessoas, 
consistindo principalmente na nomeação e na adjetivação de objetos identificáveis. A linguagem dessas crianças se caracterizava por uma repetição semelhante à dos papagaios (eram ecolálicas) e as frases eram apenas a repetição, sem qualquer modificação, de combinações de palavras ouvidas.

Kanner também observou que o sentido de uma palavra, uma vez adquirida, tornava-se inflexível e só podia ser utilizado com a conotação originalmente adquirida. Um recorte clínico ilustra tal ocorrência: um menino autista fica muito agressivo e desolado quando a mãe lhe conta que a sua analista foi para os Estados Unidos. Passa a pegar o telefone diariamente e tentar ligar para ela, chamando-a. A mãe elabora a hipótese que ele teria associado a situação da partida da analista com a única significação que admite para pessoas que partem para os Estados Unidos: no seu universo familiar, as pessoas que viajam para esse lugar nunca mais retornam, uma vez que se trata de uma decisão de emigrar e abandonar definitivamente o país de origem. Tal situação só pode ser revertida com a chegada da analista, a despeito dos esforços da mãe em explicar ao filho que não se tratava de um abandono. Uma das particularidades da linguagem dessas crianças, notada por Kanner, refere-se ao uso dos pronomes: eles são repetidos como são escutados. Resulta daí que a criança fala de si mesmo como TU, e a pessoa a quem dirige a frase como EU. Kanner complementa a observação dizendo que inclusive a entonação da fala original da mãe é repetida.

Quanto à observação da inflexibilidade do significado no uso de uma palavra, é interessante nos reportarmos ao que Lacan afirma no Seminário 3, sobre as psicoses: "a transferência do significado, tão essencial à vida humana, só é possível em virtude da estrutura do significante". Ele se pergunta o que é a comunicação e responde que o essencial da comunicação enquanto tal é o registro da mensagem, é o certificado de recepção enquanto significante, e não significativo. Diz ele:

há o uso próprio do significante a partir do momento em que, no nível do receptor, o que importa não é o efeito do conteúdo da mensagem, mas isto: que no ponto de chegada da mensagem, esta é registrada para posterior utilização. Assim, a possibilidade de usar a linguagem como comunicação está articulada à possibilidade de manejar o significante com fins puramente significantes, ou seja, como um sinal de ausência que remete a outro sinal. 
Nesse texto, Lacan vai ligar a definição de subjetividade à estrutura do significante, ao afirmar que "o subjetivo aparece no real na medida em que supõe que temos à nossa frente um sujeito capaz de se servir do significante. E servir-se do significante não para significar algo, mas precisamente para enganar sobre o que se tem a significar". Vemos então que o exercício da função da fala implica propriamente o campo daquilo que o sujeito diz sem saber, diz no desconhecimento, diz enganandose.

Para concluir, gostaria de trazer o recorte de um caso relatado na literatura por Bernard Nominé e que pode nos ajudar a retomar essas diferenciações que estão teorizadas por Lacan, especialmente o que está implicado no uso da linguagem no seu estatuto de significante que faz laço com um outro. Cito a apresentação que ele faz:

É uma criança que podemos seguramente qualificar de autista e que tem um comportamento absolutamente estereotipado. A cada vez que entra no consultório de sua psicóloga corre em direção do telefone, digita algumas teclas e logo em seguida o telefone começa a tocar. Ele consegue em suma chamar a si próprio, e jubila. Isto poderia durar horas se ele não fosse detido. Isto cria embaraços, pois não é apenas o telefone da psicóloga que toca, mas sim todos os ramais telefônicos da instituição. É claro que se faz a psicóloga entender que ela precisa deter a desordem. O único meio de fazê-lo cessar é desligando o fio do telefone. $\mathrm{O}$ garoto continua a digitar e se irrita porque isso já não funciona mais e ele não pode conceber que sua máquina não responde mais porque foi desligada. De fato, se ele sabe, não sabemos como, o que é preciso fazer para que o próprio telefone se chame, ele não tem, por outro lado, a menor idéia do que seja uma ligação. Nós que não somos autistas, temos a idéia do que significa estar ou não ligado, porque é a relação com o Outro o princípio da ligação. Nós admitimos que para satisfazer nossas necessidades e gozar um pouco da vida é melhor estar conectado ao circuito dos significantes do Outro e lhe endereçar nossas demandas. Pois bem, essa criança faz exatamente 0 contrário: ela se serve do significante - o telefone, suas teclas, sua campainha, é uma aparelhagem simbólica - mas ela não o utiliza para se endereçar ao Outro, mas sim para alimentar o seu próprio novelo, que funciona em circuito fechado. Nenhuma alteridade portanto na maneira como ele utiliza o significante. 
Deste relato, podemos retirar o seguinte elemento importante que pode servir como critério diagnóstico, a despeito da variabilidade das manifestações das crianças autistas: a criança autista não utiliza o significante para endereçar suas demandas ao Outro, ela não se serve do significante para cifrar seu gozo, mas não se pode dizer que ela não faça uso dele. Faz um uso solitário do significante que exclui qualquer forma de ligação com o Outro. Poderíamos dizer que a posição da criança autista na sua relação com o Outro pode ser definida através dos seguintes traços destacados por Colette Soler:

- são crianças perseguidas pelos signos da presença do Outro, especialmente a voz e o olhar do Outro;

- a anulação do Outro. Freqüentemente, acredita-se inicialmente tratar-se de crianças surdas, quando de fato não o são. Também apresentam distúrbios do olhar: ou não olham ou apresentam estrabismo;

- recusa da intimação do Outro, ou seja, recusa do que o Outro, pela sua palavra pode intimar, pode demandar. Este traço revela uma característica freqüentemente observada: são crianças que não demandam. A ausência de demanda é a contrapartida e o complemento da recusa de ser chamado pelo Outro. A criança autista recusa a voz e o olhar do Outro, e é através da voz e do olhar que o Outro chama o sujeito. Este ponto é importante porque sabemos que é pela demanda que o sujeito faz a sua entrada no real.

Retomando então a questão do que se passa entre a mãe e seu bebê, é preciso reconhecer que aí existe a linguagem e o gozo. E mais ainda, que há uma intrínseca articulação entre gozo e linguagem. Isto equivale a dizer que entre a mãe e a criança há uma adaptação imperfeita, da qual pode testemunhar a perda inicial do objeto placentário, o envelope. A criança não ocupa todo o espaço. Falar de fusão, de simbiose, de díade pode fazer-nos acreditar em uma unidade que é apenas imaginária. É a presença deste terceiro termo - a falta - entre a criança e a mãe que vai permitir a circulação dos objetos que realizam as trocas entre elas (o lugar vazio é fundamental para que a circulação das trocas se dê). Acontece que, em certas condições, a criança pode ser solicitada a 
obturar essa falta, decorrendo daí patologias, dentre as quais o autismo seria a condição mais radical.

Em função do que foi apresentado, podemos concluir dizendo que, se a condição da criança autista se sustenta em uma objetificação do sujeito, a única aposta possível, e que é aquela que a psicanálise faz, é supor aí um sujeito e insistir no chamado.

\begin{abstract}
Based on clinical observations of autistic children, this paper aims at identifying certain relevant aspects in order to advance the psychoanalytical approach to subjectivity, especially with regard to the importance of the consideration of the language domain and the function of speech in the structuring process. The fundamental condition of the symbolic gesture which happens at the subject's birth entwines the real organism with the discourse, implying not only social ideals but principally the incidence of a desire not to be anonymous.
\end{abstract}

Key words: autism; psycho-analysis; language; subjectivity.

\title{
REFERÊNCIAS
}

KANNER, L. Distúrbios autísticos do contato afetivo. In: ROCHA, P. S. (Org.) Autismos. São Paulo: Escuta; Recife, PE: Centro de Pesquisas em Psicanálise e Linguagem, 1997. p. 111-171.

LACAN, J. O seminário - livro 3: As psicoses. Versão brasileira de Aluísio Menezes. 2. ed. Rio de Janeiro: Jorge Zahar, 1988.

NOMINÉ, B. O autista: um escravo da linguagem. Revista Marraio - Formações Clínicas do Campo Lacaniano, n. 2, 2001, p. 11-23.

SOLER, C. Autisme et paranoia. Bulletin du Groupe Petite Enfance, n. 10, 1997. p. 22-30.

VORCARO, A. A criança na clínica psicanalítica. Rio de Janeiro: Companhia de Freud, 1997. 